\title{
STRATEGI PERBAIKAN PROSES PEMBELAJARAN MADRASAH DINIYAH ANNAFIIYAH
}

\section{Suhartinah}

\author{
Program Study Manajemen Pendididkan Islam \\ Universitas Nurul Jadid Paiton Probolinggo \\ Email: Tina.scout.enje@gmail.com.
}

\begin{abstract}
Abstrak
Dalam sebuah pendidikan agama islam memiliki sebuah lembaga yang di dalamnya hanya memuat pelajaran yang terkait agama islam saja lembaga tersebut kita kenal dengan madrasah diniyah, lembaga madrasah diniyah bukan hanya terdapat di dalam pondok pesantren tetapi di luar pesantren juga ada lembaga tersebut, karena madrasah diniyah diharapkan dapat memberikan pemahaman yang lebih luas dan tepat tentang agama islam. Dalam sebuah lembaga pendidikan sering kita temui ketidak efektifan waktu, ketidak efektifan waktu bisa disebabkan karena kurangnya jam pembelajaran atau waktu yang terbatas dan ketidak disiplinan antara guru dan murit sehingga menyebabkan ketidak efektifan waktu pembelajaran. seperti yang terjadi dalam lembaga madrasah diniyah Annafiiyah para santri cenderung lebih memilih tidur didalam kelas karena kegiatan yang sangat padat di dalam pondok maupun di lembaga formal dan waktu pembelajaran diniyah dilakukukan pada malam hari jika.
\end{abstract}

A. Pendahuluan

Dilihat dari sejarah pendidikan di Indonesia dinamika kehidupan masyarakat muslim pendidikan agama tumbuh dan berkembang di masyarakat dengan kurun waktu yang panjang, awal mula pendidikan agama dilakukan secara tradisi dan tempatnya yang digunakan di tempat-tempat sholat seperti di Masjid-masjid dan surau, pendidikan yang diajarkan meliputi pengajian al-Qur'an dan kitab.

Madrasah diniyah berkembang setelah Indonesia merdeka, pendidikan yang awalnya di lakukan dengan tradisi berubah dengan datangnya colonial disitu mulai tumbuh sekolah-sekolah umum yang didirikan di berbagai nusantara baru setelah Indonesia merdeka sebagian besar sekolah agama berpola madrasah diniyah. 
Dalam perkembangannya madrasah terbagi menjadi dua yaitu madrasah ibtidaiyah untuk madrasah yang di dalamnya terdapat pelajaran umum dan madrasah diniyah khusus pelajaran agama. Seiring dengan munculnya ide-ide pembaharuan dalam pendidikan agama, ada sebagian madrasah melakukan pembaharuaan dengan melakukan modifikasi kurikulum yang dikeluarkan departemen agama namun mereka juga menyesuaikan dengan lingkungannya. Sedangkan madrasah diniyah yang lain lebih memilih menggunakan kurikulum sendri dengan persepsi dan kemampuannya masingmasing. Biasanya madrasah diniyah dilangsungkan pada sore atau malam hari. Banyak masyarakat yang mendukung adanya madrasah diniyah karena mereka merasa pendidikan formal tidak mampu memberi pelajaran tentang islam secara keseluruhan dari itu timbul partisipasi masyarakat untuk menyekolahkan anaknya, meskipun madrasah diniyah mengalami krisis identitas karena pola pengelolahannya tidak diketahui tapi karakteristiknya yang mengangkat pengetahuan klasik tentang agama islam layak untuk di pertahankan bahkan di perbaik cara pengelolahannya.

B. Strategi Perbaikan Proses Waktu Pembelajaran Madrasah Diniyah Annafiiyah

\section{Definisi Pendidikan}

Dalam bahasa Indonesia, istilah pendidikan berasal dari "didik" dengan memberikan awalan "pe" dan akhiran "an”, mengandung arti perbuatan'(hal, cara, atau sebagainya). Kata pendidikan berasal dari bahasa Yunani yaitu paedogogos yang berarti pergaulan dengan anak-anak

Menurut Undang-Undang No.20 tahun 2003 tentang SISDIKNAS Bab I mengatakan, Pendidikan adalah mewujudkan suasana proses belajar peserta didik agar aktif yang dilakukan secara sadar dan terencana untuk mengembangkan potensi dirinya agar memiliki kekuatan spiritual keagamaan, pengendalian diri, kepribadian, kecerdasan, akhlak mulia, serta keterampilan yang dapat membawa dirinya berguna bagi, masyarakat, bangsa, dan Negara. ${ }^{1}$

Ditinjau dari proses dan tempat berlangsungnya pendidikan, dapat dikelompokkan menjadi tiga yaitu;

a. Batasan yang luas

\footnotetext{
${ }^{1}$ Ramayulis, Ilmu pendidikan Islam, (Jakarta: Kalam Mulia, 2002) 30,32
} 
Pendidikan dalam arti luas adalah segala pengalaman belajar yang dilakukan peserta didik dalam segala lingkungan dan yang terjadi sepanjang hayatnya.

b. Batasan yang sempit

Pendidikan dalam batasan yang sempit adalah proses pembelajaran yangdilaksanakan dilembaga pendidikan formal (madrasah/sekolah).

c. Batasan yang luas terbatas

Pendidikan dalam batas luas dan terbatas adalah pendidikan yang dilakukan oleh keluarga, sekolah, masyarakat, dan pemerintah melalui kegiatan bimbingan pengajaran dan dilaksanakan sepanjang hayat, dalam rangka mempersiapkan peserta didik agar berperan dalam kehidupan. ${ }^{2}$

Dalam pemberdiknas No.22 Tahun 2007 mengemukakan tujuan sebuah pendidikan di tingkat satuan dasar dan menengah rumusunnya mengacu kepada tujuan umum pendidikan yang tujuannya sebagai berikut:

a. Tujuan pendidikan dasar adalah sebuah pendidikan yang menerapkan pengetahuan, kecerdasan, kepribadian, akhlak mulia serta dapat hidup mandiri dan dapat melanjutkan pendidikannya.

b. Tujuan pendidikan menengah adalah sebuah pendidikan yang menerapkan pengetahuan, kecerdasan, kepribadian, akhlak mulia serta dapat hidup mandiri dan dapat melanjutkan pendidikannya.

c. Tujuan pendidikan menengah kejuruan adalah sebuah pendidikan yang menerapkan pengetahuan, kecerdasan, kepribadian, akhlak mulia serta dapat hidup mandiri dan dapat melanjutkan pendidikan sesuai dengan kejuruannya. Penjabaran tujuan pendidikan institusional kedalam tujuan kurikuler yaitu tercapainya setiap mata pelajaran yang dikembangkan dalam sebuah lembaga atau suatu pendidikan. ${ }^{3}$

\section{Pengertian Madrasah Diniyah}

\footnotetext{
22 Ramayulis, Ilmu pendidikan Islam, (Jakarta: Kalam Mulia, 2002) 39-40

${ }^{3}$ Hasan Baharun, Pengembangan Kurikulum Teori dan Praktik, (Karanganyar Paiton Probolinggo: Pustaka Nurja, 2017) (hlm .41-42.
} 
Madrasah diniyah adalah sebuah lembaga pendidikan keagamaan yang berada pada jalur luar sekolah atau non formal yang berada dalam naungan pesantren. lembaga tersebut diharapkan dapat memberikan pemahaman yang lebih luas tentang pendidikan agama islam yang tidak dapat di peroleh dari lembaga pendidikan formal. Karena yang kita ketahui bersama pendidikan formal hanya sedikit pelajaran yang mengandung nilai agama jadi disitulah dibutuhkan pemantapan dan peluasan pengetahuan agama melalui lembaga madrasah diniyah

Dalam madrasah diniyah terdapat beberapa tahapan atau tingkatan dalam pembelajaran, bagi pemula atau tingkat dasar di kelompokkan dalam tingkatan Awaliyah sedangkan untuk tingkatan menengah atau pengembangan pengetahuan di kelompokkan pada tingkkatan wustho, dan tingkatan terakhir yaitu Ulya untuk tingkatan menengah atas

Dalam sejarah, dimasa penjajahan Jepang sudah hadir madrasah awaliyah sebagi Madrasah diniyah yang pertama dengan pengembangan yang sangat luas. Sedangkan pengagas sekaligus penggerak pendirinya madrasah awaliyah adalah majlis tinggi Islam. Program awwaliyah ini lebih ditekankan kepada pembinaan keagaman yang diselenggarakan pada sore hari. Madrasah awaliyah diperuntukkan anak-anak yang berumur dibawah tujuh tahun.

Berdasarkan undang-undang pendidikan dan peraturan pemerintah, lembaga Madrasah diniyah dapat memenuhi permintaan masyarakat tentang pendidikan agama sehingga madrasah diniyah termasuk bagian dari pendidikan nasional.

Secara umum terdapat beberapa karakteristik pendidikan Madrasah diniyah yang ada di Nusantara, pertama madrasah Diniyah Takmiliyah atau (suplemen) madrasah diniyah tersebut berada di masyarakat dan tidak terikat dengan pondok, diniyah ini betul-betul memproritaskan masyarakat yang diperuntukkan bagi anak-anak yang tidak mampu mondok, mereka bisa mempelajari pengetahuan agama di luar jalur pendidikan formal. Yang kedua pendidikan Diniyah yang berada di dalam lingkaran pondok pesantren yang bahkan pondok pesantren tersebut menjadikan pendidikan madrasah diniyah sebagai urat nadi dalam kegiatan pondok pesantren. Ketiga pendidikan dinyah yang dilakukan di luar pondok pesantren dan pembelajarannya dilakukan pada pagi hari dan secara formal layaknya sekolah formal. 
Di dalam lembaga Diniyah memuat sejumlah pelajaran tentang agama islam seperti Qur'an Hadits, Aqidah Akhlak, Fiqih, Sejarah Kebudayaan Islam, Bahasa Arab praktek Ibadah dan lain sebagainya yang berkaitan dengan agama Islam atau penunjangannya.

Kurikulum yang digunakan oleh lembaga Diniyah dapat tertulis dan tidak tertulis (pasal. 12 ayat 2). Bahwa Madrasah Diniyah adalah bagian terpadu dari sistem pendidikan nasional untuk memenuhi hasrat masyarakat dalam pendidikan islam yang dilakukan pada jalur luar sekolah. Berdasarkan Undang-undang pendidikan no 73 tahun 1991 pasal 1 ayat 1 disebutkan " penyelenggaraan pendidikan diluar sekolah boleh dilembagakan dan boleh tidak dilembagakan". Dengan jenis "pendidikan Umum" (pasal 3 ayat 1.). Pembinaan mentri agama terhadap Madrasah Diniyah yang dilakukan diluar jalur sekolah dan dilembagakan bertujuan untuk mengembangkan dan mempersiapkan peserta didik terhadap pengetahuan agama Islam berada pada (PP 73, pasal 22 ayat 3). Untuk membantu masyarakat dalam rangka tercapainya tujuan pendidikan yang terarah, sistematis dan tersruktur derektoral Jendral jendral kelembagaan pembinaan agama menetapkan kurikulum Madrasah diniyah. Meskipun demikian masyarakat diberikan keleluasaan untuk mengembangkan isi pendidikan sesuai dengan keadaan dan kebutuhan Madrasah. Pada dasarnya kurikulum Madrasah Diniyah bersifat fleksibel dan akomodatif. Oleh karena itu pengembangan kurikulum Madrasah Diniyah dapat dilakukan oleh Departemen agama pusat kantor wilayah/ Depak Propinsi dan kantor Depak Agama Kabupaten atau bisa dilakukan oleh pengembangan pendidikan sendiri yang terpenting pengembangan kurikulum tersebut tidak melanggar aturan perundang-undangan yang berlaku tentang pendidikan secara umum, dan tidak menyalahi peraturan yang telah ditetapkan oleh mentri Agama, peraturan pemerintah maupun kebijakan lainnya yang berkaitan dengan penyelenggaraan pendidikan Madrasah Diniyah.

dengan meninjau berlangsungnya kegiatan madrasah diniyah dapt kita lihat ada beberapa karakteristik dalam pembelajaran madrasah diniyah terdapat ciri-ciri sebagai berikut

1). Madrasah diniyah sebagai pelengkap sekolah formal 
2). Madrasah diniyah dapat dilakukan dimana saja tanpa persyaratan yang ketat serta dapatdisesuaikan dengankebutuhan

3). Madrasah diniya tidak dibagi atas tingkatan-tingkatan kelas dengan ketat

4). Madrasah diniyah dalam materinya bersifat praktis dan khusus

5). Madrasah diniyah melakukan pembelajaran relative singkat

6). Madrasah diniyah mempunyai metode pengajaran yang bermacam-macam

3. Analisi Proses Waktu Pembelajaran Madrasah Diniyah Annafiiyah

Pondok pesantren sebagai lembaga pendidikan Islam banyak mendapat sorotan dari berbagai pihak dalam rangka mencerdaskan dan mencapai tujuan pendidikan di negara Indonesia.

Kata pesantren identik dengan agama yang mendalam jika kita melihat banyak pondok pesantren yang didalamnya memprogramkan kegiatan pendidikan para santrinya 24 jam atau fullday mereka di biasakan dalam berbagai hal tentang keagamaan, dan pengetahuan umum, ${ }^{4}$ Di dalam kegitan tersebut terdapat sebuah lembaga madrasah diniyah dimana madrasah tersebut dikhususkan untuk memberikan pemahaman secara mendalam tentang agama Islam, waktu pembelajaran madrasah diniyah annafiiyah berlangsung pada malam hari setelah sholat isya' karena sekolah formal dimulai dari jam 07.00 sampai dengan 15.00. Sebagian pengetahuan santri tentang agama islam di peroleh dari lembaga tersebut disana terdapat beberapa tahap atau tingkatan menurut kemampuan peserta didik. Yang kita lihat di dalam madrasah diniyah Annafiiyah terdapat tiga tingkatan, tingkatan untuk pemula di kelompokkan dalam tingkatan awaliyah dan di dalam tingkatan awaliyah terdapat tiga tingkatan lagi yaitu awaliyah satu, awaliyah dua dan awaliyah tiga, jika sudah dirasa mampu berada di awaliyah tiga maka peserta didik tersebut dipindahkan kedalam tingkatan wustho dan didalam tingkatan wustho juga terdapat tiga tingkatan lagi seperti halnya awaliyah, jika dirasa mampu berada di wustho tiga maka akan di kelompokkan dalam tingkatan ulya dimana tingkatan ulya adalah tingkatan terakhir namun di dalam tingkatan ulya juga terdapat tiga tingkatan, jika tiga tingkatan tersebut sudah berhasil dilalui maka anak didik tersebut layak untuk wisuda.

\footnotetext{
${ }^{4}$ Rifa'l, Commonity Empowerment in Islamic Boarding School, ( Kraksaan Probolinggo: Mandiri2017) 02
} 
dalam madrasah diniyah Annafiiyah terdapat satu pengelompokan lagi namun bukan sebuah tingkatan pencapaiaan target kelulusan. kelompok atau kelas tersebut adalah kelompok tahassus dimana di kelas ini khusus mahasisiwi di dalam tahassus ini juga ada tiga tingkatan kelas A, B, dan C, dalam kelas tahassus tidak ada kenaikan kelas jika mereka sudah mampu maka maka tidak wajib mengikuti kelas tahassus di tahun berikutnya, bagi mahasisiwi baru alumni atau bukan alumni diwajibkan sekolah diniyah selama satu tahun jika mereka sudah dirasa mampu dengan adanya tes yang dilakukan pada tahun tersebut maka mahasiswi tersebut sudah tidak perlu mengikuti pendidikan madrasah diniyah di tahun selanjutnya namun jika mahasiswi tersebut tidak mampu maka tahun berikutnya dia wajib mengikuti kelas kembali,

Meskipun Madrasah Diniyah telah mendapat hak hukum sebagaimana yang tertera dalam Undang-undang peraturan pendidikan Republik Indonesia No 20 tahun 2003 tentang Sisdiknas yang kemudian mengalami transpormasi PP 55 tahun 2007 tentang pendidikan agama dan pendidikan keagamaan, namun pendidkan Madrasah Diniyah masih banyak problem-problem yang terjadi di dalam lembaga madrasah tersebut begitupun yang terjadi dalam lembaga Madrasah Diniyah Annafiiyah.

Karena Madrasah diniyah Annafiiyah berada dalam naungan pesantren Nurul Jadid jadi waktu pembelajarannya harus mengikuti prosedur-prosedur yang ada dalam pesantren. Di dalam waktu pembelajaran Madrasah Diniyah Annafiiyah berlangsung pada malam hari dikarenakan padatnya kegiatan pada siang hari, setelah ngaji subuh para santri wajib sekolah formal sampai sore dan dilanjutkan dengan kegiatan-kegitan yang lain sehingga jam masuk diniyah baru bisa berlangsung setelah bakda sholat isyak hal itu menjadi kendala yang menimbulkan ketidak efektifan waktu dalam pembelajaran. tempat berlangsungnya pembelajaran di adakan dalam kelas sesuai dengan kemampuannya tidak dibedakan antara siswi SLTP dan SLTA di sekolah formal mereka benar2 dibentuk sesuai kemampuannya sehingnga pembelajaran peserta didik dapat terkontrol

Ketidak efektifan waktu juga ditimbulkan dari para muallim yang terlambat datang, alasan para muallim adalah saat mereka masuk kelas masih sedikit peserta didik yang hadir jadi mereka masuk kelas lebih lambat. dan para santri juga banyak yang mengeluh kelelahan karena kegiatan yang berlangsung dari pagi, dengan 
demikian banyak dari para santri yang memilih tidak sekolah atau tidur dikelas hal itu sudah menjadi proritas utama para santri jika pelajaran berlangsung mayoritas peserta didik sudah terlelap walaupun ustad memberi sangsi namun mereka tetap tertidur. jika lampu padam atau gerimis banyak santri yang tidak masuk sekolah, dari situ banyak waktu yang terbuang karena ketidak efektifan waktu pembelajaran sehingga menimbulkan pembelajaran tidak mencapai target yang telah direncanakan

4. Perbaikan Proses Waktu Pembelajaran

Jika dilihat dari penyebab-penyebab terjadinya ketidak efektifan waktu pembelajaran bisa di simpulkan kendala terbesar berada pada waktu pembelajaran yang berlangsung pada malam hari jika waktu pembelajaran dipindah pada pagi hari

- Keterlambatan guru, akan berkurang karena jam pembelajaran akan langsung di sambungkan dengan pembelajaran sekolah formal,

- alasan mati lampu dan kelelahan, karena proses belajar berlangsung pada pagi hari, alasan mati lampu dan kelelahan tidak dapat digunakan lagi oleh santri, santri yang tidak sekolah diniyah berarti juga tidak bisa sekolah formal karena jam pembelajarannya akan langsung dilanjutkan dengan sekolah formal.

Selain itu jika pembelajaran di lakukan pada pagi hari tidak menutup kemungkinan pelajaran yang mereka dapat bisa terserap karena selain tubuh mereka yang masih segar tentunya fikiran mereka juga masih lancer.

\section{Kesimpulan}

Ketidak efektifan waktu pembelajaran bisa terjadi karena jam masuk sekolah yang kurang tepat sehingga membuat pembelajaran tidak mencapai target yang direncanakan, maka solusi peminiman ketidak efektifan waktu pembelajaran dapat memindahkan jam pembelajaran tersebut Karena jika kita melihat dari problematika yang terjadi kendala terbesar yang menyebabkan ketidak efektifan waktu para pengajar dan peserta didik karena waktu pembelajaran yang dilakukan pada malam hari. 


\section{DAFTAR RUJUKAN}

Ramayulis.2002. Ilmu pendidikan Islam. (Jakarta: Kalam Mulia).

Rifa'I.2017. Commonity Empowerment in Islamic Boarding School. (Kraksaan Probolinggo: Mandiri)

Mundiri, A. (2016). THE LEADERSHIP OF HEADMASTER IN BUILDING A WORK CULTURE BASED ON PESANTREN. In International Conference on Education and Training (pp. 1-7). Malang: Faculty of Education State University of Malang.

Mundiri, A. (2017). Organizational Culture Base On Total Quality Management In Islamic Educational Institution. ADRI International Journal Of Islamic Studies and Social Sciences, 1(1), 1-11.

Mundiri, A., \& Zahra, I. (2017). Corak Representasi Identitas Ustadz dalam Proses Transmisi Pendidikan Karakter di Pesantren. Jurnal Pendidikan Islam, Vol. 2, No, 21-35.

Hasan Baharun. 2017. Pengembangan Kurikulum Teori dan Praktik, (Karanganyar Paiton

Probolinggo: Pustaka Nurja)

https://www.terwujud.com/2014/02/pengertian-madrasah-diniyah.html

http://kuliyyatul.blogspot.com/2013/03/pengertian-madrasah-diniyah.html

http://www.anekamakalah.com/2012/06/madrasah-dinivah-problema-dan-solusi.html 